\title{
Evaluation of landslide hazard and its impacts on hilly environment of the Nilgiris District - a geospatial approach
}

\author{
Edison Thennavan and Ganapathy Pattukandan Ganapathy*
}

\begin{abstract}
Landslide Hazard Zonation (LSH) maps play a key role in landuse planning particularly in landslide prone areas. LSH mapping is globally accepted one for analyzing the area for landslide susceptibility. Different approaches were followed by many researchers in India to prepare landslide hazard zonation mapping depending upon their need and requirement. The Nilgiris district in Western Ghats of India is one of the severe to high landslide hazard prone areas of India. Many agencies have carried out research on LSH mapping for the Nilgiris district with different scales. A systematic study of inventory and zonation was 122carried out in 1980's by government agencies. However there is no proper updation or documentation on landslides after 1980's in the district The purpose of this paper is to review the existing landslide-related studies in the district of The Nilgiris and review the district's existing landslide hazard map with updated information. Landslide hazard maps in The Nilgiris were compiled in the GIS platform from various authenticated sources. Data on landslides from 1824 to 2014 were collected and a spatial database on landslides was created. A detailed inventory was analyzed and used for revision of the district's landslide hazard impact on the 2009 landslides.. Based on the landslide inventory and densely populated areas and repeated landslides at the same locations, the most landslide hazard areas were identified.
\end{abstract}

Keywords: Landslide, Hazard zonation, Mapping, GIS, The Nilgiris, Western Ghats

\section{Introduction}

Landslide hazard is commonly shown on maps, which display the spatial distribution of hazard classes. Landslide hazard zonation refers to "the division of the land in homogeneous areas or domains and their ranking according to degrees of actual/potential hazard caused by mass movement" (Varnes 1984). Scientists are globally working on landslide studies and particularly on LSH studies. India is one among the countries highly prone to landslide hazard. The landslide hazard zonation atlas of India shows that many parts of India are prone to very high to severe landslide hazard (BMTPC 2002). Some of the densely populated hill areas fall under this category. Various methods have been deployed to prepare LSH maps by various researchers along the globe. Researchers have been using various qualitative and quantitative approaches/techniques to derive the hazard

\footnotetext{
* Correspondence: seismogans@yahoo.com

Centre for Disaster Mitigation and Management, Vellore Institute of Technology (VIT), Vellore, Tamil Nadu 632014, India
}

areas viz., Distribution (inventory) approach, Statistical approach, Bi-variate statistical analysis, Weights of evidence model, Weighted overlay method, Frequency ratio approach, Information Value Method (IVM), Bureau of Indian Standard (BIS) based Landslide Hazard Evaluation Factor (LHEF) method, Fuzzy logic method, Multivariate statistical analysis, Logistic Regression (LR) analysis, Discriminant analysis method, Artificial neural network method, Multivariate analysis, Probabilistic approach, Analytic hierarchy process approach, Rainfall threshold model, Physically-based landslide susceptibility models. The qualitative approaches are very popular in late 1970's and the quantitative approaches are become popular in last decades (Kanungo et al. 2009). The Nilgiris district in the Western Ghats of India is one of the severe to high landslide hazard areas of India (Fig. 1). Many researchers carried out landslide hazard studies in The Nilgiris district (Seshagiri et al. 1982; Ramakrishnan et al. 2002; Rajarathnam and Ganapathy 2006; Rajkumar et al. 2007; Vasantha Kumar and Bhagavanulu 2007; 


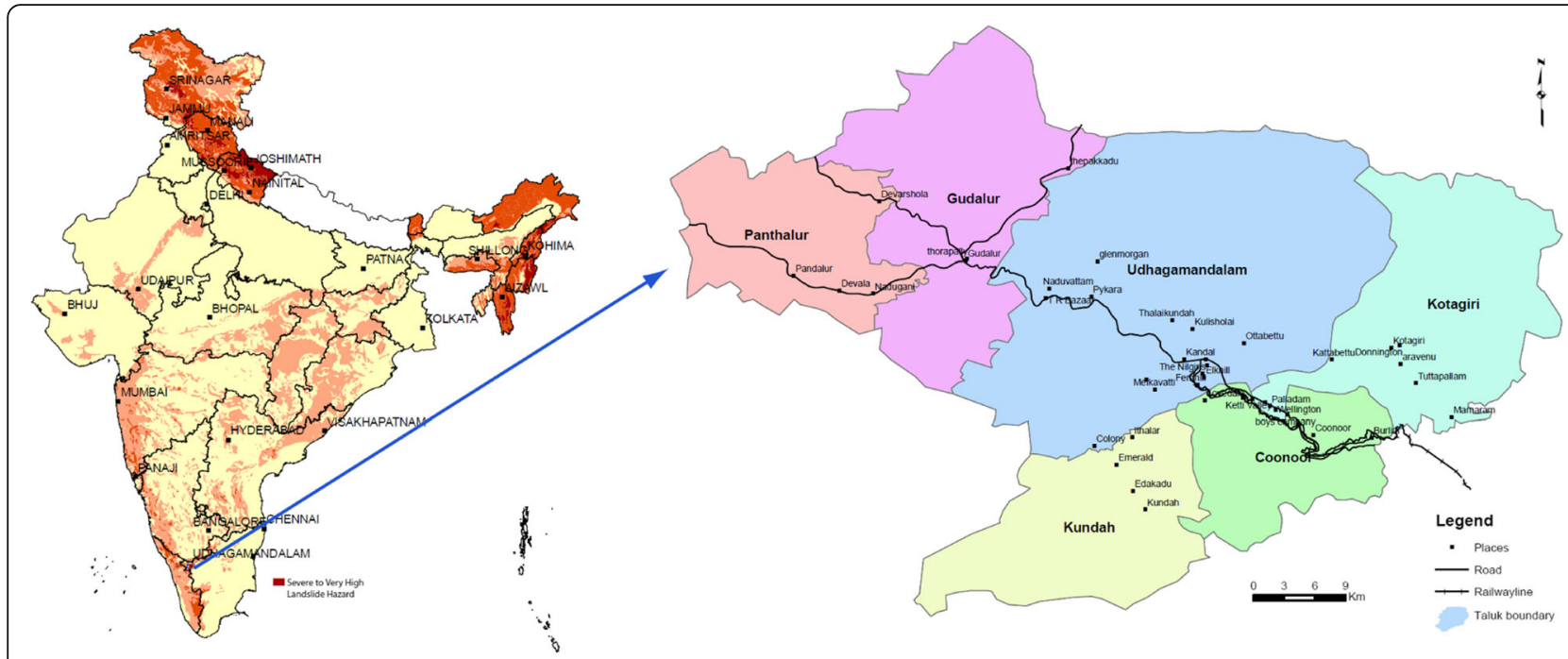

Fig. 1. Location map of the study area on the landslide hazard zonation map of India

Thanavelu and Chandrasekaran 2008; Ganapathy and Jothimani 2009; Jaiswal and van Westen 2009; Jaiswal Jaiswal et al. 2010a,Jaiswal et al. 2010b,Jaiswal et al. 2011a,Jaiswal et al. 2011b; Naveen Raj et al. 2011; Antony and Ramanujan 2012; Ganapathy et al. 2012; Manimaran et al. 2012; Prabu and Ramakrishnan 2012; Pradeep Kishore et al. 2012; Vaani and Sekar 2012; Gurugnanam et al. 2013; Sunandana and Lakshmikanta 2013; Gomathi et al. 2013; Chandrasekaran et al. 2013; Muthukumar 2013; Bairavi et al. 2014; Nalina et al. 2014; Ganapathy and Rajawat 2015). The Nilgiris district has lengthy history of landslides and it created more damage to property and infrastructure, however the loss of life is less when compared to landslide impacts in other parts of India. Even though many of them carried out research on landslide hazard zonation, most of the studies are not properly validated with field evidences and lack of database. The present paper aims to bring out a document on the past history of landslides in The Nilgiris and revise the landslide hazard zonation impact map of The Nilgiris district, Western Ghats of India.

\section{Study area}

The Nilgiris district of Western Ghats parts of Tamil Nadu has an extensive history of landslides. The occurrences of landslides in the district are almost seasonal. The months of October \& November are prone to landslides. The years 1902, 1978, 1979, 1993, 2001, 2006 and 2009 are notable years for landslides in the history of The Nilgiris district. In November 1891 heavy rain caused many landslips on the Coonoor Ghat, and created more damage to the Kotagiri - Metuppalayam road (Ganapathy and Rajawat 2015). The old and new Coonoor railway was blocked for a month and the ghat roads for nearly as long; and all the traffic of the eastern side of the plateau was thrown upon the Kotagiri ghat, which was itself in a perilous condition-slips having occurred throughout and being serious in six places out of its twenty one miles ( $34 \mathrm{kms})$ length during December 1902. Boulders disrupted the railway movement between Adderley and Runneymede railway stations and subsidence were reported near Katteri railway station in the year 1926 (GSI, 1982). Arogyaswamy 1967 mentioned a large landslide was reported in a peat Landen area on the left flank of Emerald Valley. Balasundaram reported rock slides in July 1952 and November 1958 in Penstock of Nilgiri. In the year 1961 a large pre existing landslide was examined by Srinivasan in the Porthimund Dam (Seshagiri et al. 1982). During 1978, unprecedented rains triggered about a hundred landslides in the district over an area of 250sq.kms. Many people were killed in Ooty on 5 November 1978 due to the collapse of houses, landslides and drowning. During 1979, nearly 200 landslides were recorded, resulting in loss of life and serious property damage. Although it is known that the Nilgiri and other mountainous areas are susceptible to landslides, occurrences of this magnitude were previously unknown. Continuous heavy rainfall occurred between 12 and 19 November 1979, with heavy $102.2 \mathrm{~mm}$ rain in Coonoor and a heavy landslide in Selas where a house was completely buried in the debris together with two women and three children. Another 'cloud burst 'occurred in the upper reach of Coonoor Taluk's Marappalam on 11 November 1993, damaging about 18 huts below the road and washing off Coonoor MTP Ghat Road for about $11 / 2 \mathrm{~km}$ (Ganapathy et al. 2010). For more than a fortnight, road traffic was suspended. Twelve people were killed and fifteen people were missing. Twenty-one passengers with two buses were washed away. Landslide damaged the railway station and a 
Table 1 Historical landslides and the damage consequence in the Nilgiris District

\begin{tabular}{|c|c|c|c|c|c|}
\hline SI.No & Year & Places & $\begin{array}{l}\text { Damage to } \\
\text { Infrastructure }\end{array}$ & $\begin{array}{l}\text { Damage } \\
\text { to Houses }\end{array}$ & $\begin{array}{l}\text { Death } \\
\text { Reported }\end{array}$ \\
\hline 1 & 1824 & $\begin{array}{l}\text { Avalanches slide- Sliced a part of Kudikkadu hills of Kundah area after } 8 \text { days of heavy } \\
\text { rain, recorded by Harness, Baike and Benza }\end{array}$ & Yes & No & No \\
\hline 2 & $\begin{array}{l}23 r d \\
\text { October } \\
1865\end{array}$ & $\begin{array}{l}\text { Worst Storm on record occurred around Ooty and Coonoor. Coonoor Railway station } \\
\text { was covered with water up to five feet deep. In Ooty Lake water rose up to top of } \\
\text { willow bound and threatened to breach it. }\end{array}$ & Yes & Yes & No \\
\hline 3 & 1881 & Slides on Kothagiri - Mettupalayam and Coonoor Ghat Roads & Yes & Yes & No \\
\hline 4 & $\begin{array}{l}\text { November } \\
1891\end{array}$ & $\begin{array}{l}\text { Storm caused many landslips on the Coonoor Ghat, and did great damage to the } \\
\text { Kotagiri - Metuppalayam road. Affected traffic for a week after a record of } 74 \mathrm{~cm} \text { rain } \\
\text { within a few days }\end{array}$ & Yes & Yes & No \\
\hline 5 & $\begin{array}{l}\text { December } \\
1902\end{array}$ & $\begin{array}{l}\text { Twenty one inches of rain (three times the average amount) fell in that month in } \\
\text { Coonoor, and at Kotagiri } 24 \text { in. (six times the average amount) was received, of which } \\
8.45 \text { in. fell in a single night. The Coonoor railway was blocked for a month the old and } \\
\text { new Coonoor railway was blocked for a month the old and new Coonoor ghat roads } \\
\text { for nearly as long; and all the traffic of the eastern side of the plateau was thrown upon } \\
\text { the Kotagiri ghat, which was itself in a perilous condition -slips having occurred } \\
\text { throughout and being serious in six places out of its twenty one miles length. }\end{array}$ & Yes & Yes & No \\
\hline 6 & $\begin{array}{l}\text { 4th October } \\
1905\end{array}$ & $\begin{array}{l}6.8 \mathrm{in} \text {. of rain fell at Coonoor in three hours and the Coonoor river and its effluents } \\
\text { came down in heavy and sudden floods, the former sweeping right over the parapet of } \\
\text { the bridge near the railway-station. The families of the station staff had to be rescued } \\
\text { by breaking open the back windows of their quarters with crowbars. }\end{array}$ & Yes & Yes & No \\
\hline 7 & 1926 & $\begin{array}{l}\text { Subsidence of more than a metere near Katteri Railway Station and slips near } 16 \mathrm{~km} \\
\text { and } 2.35 \mathrm{~km} \text { stones on the railway track }\end{array}$ & Yes & No & No \\
\hline 8 & 1927 & Debris fall near Adderly and Runnymede railway stations & Yes & & \\
\hline 9 & July 1952 & Rock Slides along Kundah Penstock & No & No & No \\
\hline 10 & $\begin{array}{l}\text { November } \\
1958\end{array}$ & Rock Slides along Kundah Penstock & No & No & No \\
\hline 11 & 1961 & Slide on the left flank of Porthimund dam & Yes & No & No \\
\hline 12 & 1967 & Slide on the left flank of Emerald valley & No & No & No \\
\hline 13 & $\begin{array}{l}\text { 5th } \\
\text { November } \\
1978\end{array}$ & $\begin{array}{l}323 \mathrm{~mm} \text { of rain was recorded at Ooty of which } 243 \mathrm{~mm} \text { was during the night-between } \\
5.00 \mathrm{pm} \text { of } 4 \text { th and } 8.00 \text { am of } 5 \text { th. Many people were killed in Ooty on account of } \\
\text { houses collapses, landslides and drowning. Reports were also received regarding the } \\
\text { causalities due to landslides and floods in Kookalthorai; Madithorai; Adashola and Kallatti } \\
\text { areas of Uthagamandalam Taluk and Manthada of Coonoor Taluk. }\end{array}$ & Yes & Yes & Yes \\
\hline 14 & $\begin{array}{l}\text { November } \\
1979\end{array}$ & $\begin{array}{l}\text { Heavy rainfall started from 12th November } 1979 \text { and the highest rain fall was } 114.5 \mathrm{~mm} \\
\text { at Kodanad. On 13th it was } 149.4 \mathrm{~mm} \text { at Coonoor and } 169.9 \mathrm{~mm} \text { at Kodanad. On the } \\
15 \text { th night heavy landslide had occurred at Doddacombai, on 16th night there was } \\
\text { heavy rain at Coonoor resulting in washing away of one woman and } 2 \text { Children. The } \\
\text { rainfall recorded at Coonoor and Kodanad was } 145.2 \mathrm{~mm} \text { and } 142.2 \mathrm{~mm} \text { respectively. } \\
\text { On 19th there was heavy landslide of } 100 \text { yards in width and about } 1.00 \mathrm{~km} \text { in length in } \\
\text { Selas of Ketti Village of Coonoor Taluk resulting in filling up of a Valley of } 30^{\prime}-50^{\prime} \text {. The } \\
\text { heaviest rainfall of the day was } 187.6 \mathrm{~mm} \text { at Coonoor. On } 20-11-1979 \text { also, there was } \\
\text { heavy rain of } 102.2 \mathrm{~mm} \text { at Coonoor and a heavy landslide at Selas in which a house } \\
\text { was completely buried in the debris along with } 2 \text { women and } 3 \mathrm{children} \text {. The rainfall re- } \\
\text { corded on that day at Kotagiri, Kodanad and Kundah was } 90.4 \mathrm{~mm} \text {, } 99.8 \mathrm{~mm} \text { and } 78.0 \\
\mathrm{~mm} \text { respectively. There was heavy rainfall of } 71.0 \mathrm{~mm} \text { at Devala on } 21 \mathrm{st} \text {. On 28-11-79 } \\
\text { also there was heavy rain of } 144.2 \mathrm{~mm} \text { at Coonoor. }\end{array}$ & Yes & Yes & Yes \\
\hline 15 & $\begin{array}{l}25 \text { th } \\
\text { October } \\
1990\end{array}$ & $\begin{array}{l}\text { The North East Monsoon was heavy and there was a 'cloud burst'. More than } 35 \\
\text { families were buried alive in a place called Geddai. }\end{array}$ & Yes & Yes & Yes \\
\hline 16 & $\begin{array}{l}\text { November } \\
1993\end{array}$ & $\begin{array}{l}\text { There was another 'cloud burst' on 11-11-1993 in the upper reach of Marappalam of } \\
\text { Coonoor Taluk, about } 18 \text { huts situated below the road and washing away Coonoor MTP } \\
\text { ghat Road for about } 11 / 2 \mathrm{k} \text {.m. The Road traffic was suspended for more than a fort night. } \\
12 \text { persons lost their live and } 15 \text { persons missing } 21 \text { passengers were washed away with } \\
\text { two buses. An important highway, sheared stretched of rail road for about } 300 \mathrm{~m} \text {. Out } \\
\text { of } 408 \text { landslides were reported among those Marappalam is severe one. }\end{array}$ & Yes & Yes & Yes \\
\hline 17 & $\begin{array}{l}\text { November } \\
1995\end{array}$ & $\begin{array}{l}\text { Debris flow washed away culvert and caused damage to NH } 67 \text { road near Pudukkadu } \\
\text { Village. }\end{array}$ & Yes & NA & No \\
\hline 18 & 11th & Due to continuous rain fall, one big boulder weighing about $20 \mathrm{~m}$ tonnes fell an the & Yes & Yes & No \\
\hline
\end{tabular}


Table 1 Historical landslides and the damage consequence in the Nilgiris District (Continued)

\begin{tabular}{|c|c|c|c|c|c|}
\hline SI.No & Year & Places & $\begin{array}{l}\text { Damage to } \\
\text { Infrastructure }\end{array}$ & $\begin{array}{l}\text { Damage } \\
\text { to Houses }\end{array}$ & $\begin{array}{l}\text { Death } \\
\text { Reported }\end{array}$ \\
\hline & $\begin{array}{l}\text { December } \\
1998\end{array}$ & $\begin{array}{l}\text { Coonoor Mettupalayam main road and the road was closed for traffic, the rock was } \\
\text { blasted and earth slips were removed and traffic was resumed from } 14 \text { to } 12-98 .\end{array}$ & & & \\
\hline 19 & $\begin{array}{l}\text { December } \\
2001\end{array}$ & $\begin{array}{l}\text { Due to continuous rainfall, two massive landslides occurred near Pudukadu on the } \\
\text { Coonoor-Mettupalayam high way damaging two bridges resulting in the complete clos- } \\
\text { ure of traffic. In addition damage was also caused to the railway track between Coonoor } \\
\text { - Mettupalayam. Bridge No. } 55 \text { near hill grove railway station was completely damaged } \\
\text { and Bridge No.56 was also damaged. }\end{array}$ & Yes & Yes & No \\
\hline 20 & $\begin{array}{l}\text { November } \\
2006\end{array}$ & $\begin{array}{l}\text { Consequent upon continuous heavy rains in the Nilgiri Hills, numerous landslides were } \\
\text { reported to have occurred at the early hours on } 14-11-2006 \text { killing one and injuring } \\
\text { three persons and disrupting traffic in } \mathrm{NH}-67 \text { and blocking of Mountain Rail track be- } \\
\text { tween Mettupalayam and Coonoor (nilgiris.nic.in). }\end{array}$ & Yes & Yes & No \\
\hline 21 & $\begin{array}{l}15 \\
\text { November } \\
2009\end{array}$ & About 1100 landslides/landslips taken away 45 lives. Heavy damage on houses. & Yes & Yes & Yes \\
\hline 22 & $\begin{array}{l}28 \\
\text { November } \\
2011\end{array}$ & Below Sathya Sai Nagar, Ooty-Coonoor national highway & Yes & No & No \\
\hline 23 & $\begin{array}{l}10 \\
\text { September } \\
2012\end{array}$ & Devala, Gudalur, Transportation got affected & Yes & No & No \\
\hline 24 & $\begin{array}{l}\text { 220ctober } \\
2012\end{array}$ & Ooty to Coonoor railway line got affected & Yes & No & No \\
\hline 25 & $\begin{array}{l}25 \\
\text { November } \\
2013\end{array}$ & Heavy Rain caused landslips & Yes & No & No \\
\hline 26 & $\begin{array}{l}01 \text { October } \\
2014\end{array}$ & Landslips at Manjur Aavukkal & Yes & No & No \\
\hline 27 & $\begin{array}{l}21 \text { January } \\
2014\end{array}$ & Landslips at Katteri, Paikkara, Coonoor & Yes & No & No \\
\hline 28 & $\begin{array}{l}21 \text { October } \\
2014\end{array}$ & Landslips at Gandhipuram, Coonoor & Yes & No & No \\
\hline 29 & $\begin{array}{l}22 \text { October } \\
2014\end{array}$ & Houses damaged by landslips at Anbu Anna Colony, Ooty & No & Yes & No \\
\hline 30 & $\begin{array}{l}24 \text { October } \\
2014\end{array}$ & Landslip at Railway lineAruvankadu, Ketty & Yes & No & No \\
\hline 31 & $\begin{array}{l}\text { 8th } \\
\text { November } \\
2015\end{array}$ & Landslip at Kallar - Adderley, Railway Line & Yes & No & No \\
\hline 32 & $\begin{array}{l}\text { 13th } \\
\text { November } \\
2015\end{array}$ & Rockfall at Manthada, Ooty - Coonoor Road & Yes & No & No \\
\hline 33 & $\begin{array}{l}\text { 15th } \\
\text { November } \\
2015\end{array}$ & Landslip at Kaikatti Maniapuram, Kolakambai & No & No & No \\
\hline 34 & $\begin{array}{l}\text { 20th } \\
\text { November } \\
2015\end{array}$ & Landslip at Manjur Kinnakorai Road / Aravankadu - Coonoor Mettupalayam Road & Yes & No & No \\
\hline 35 & $\begin{array}{l}\text { 21st } \\
\text { November } \\
2015\end{array}$ & Six landslips at Velankanni Nagar, Coonoor Mettupalayam, Burliar Road & Yes & No & No \\
\hline 36 & $\begin{array}{l}\text { 22nd } \\
\text { November } \\
2015\end{array}$ & Landslip caused wall collapse in Yellanahalli - Coonoor Road & Yes & Yes & No \\
\hline 37 & $\begin{array}{l}\text { 22nd } \\
\text { November } \\
2015\end{array}$ & Landslip at M. Kaikatti Pandian Nagar, Kotagiri - A female injured & No & Yes & Yes \\
\hline
\end{tabular}


bridge in December 2001. A stretch over $300 \mathrm{~m}$ along with a railway was damaged by a major highway (Ganapathy and Hada 2012). In the early hours of 14 November 2006, numerous landslides were reported, killing one and injuring three people and disrupting traffic on $\mathrm{Na}-$ tional Highway 67 and blocking the mountain railway between Mettupalayam and Coonoor (Thanavelu and Chandrasekaran 2008).

Recently, in the Nilgiri Hills, casualties and damage caused by landslides have increased.. In 2009, heavy rains triggered a series of landslides in The Nilgiris regions of Ooty, Coonoor and Kotagiri.. On 10 November 2009, 42 people died within 48 h.. Seven of a family died near Ooty in the hamlet of Acchanakal.. Also the slides and uprooted trees cut off access via Mettupalayam to The Nilgiris. From Coonoor via Mettupalayam, the approach road to Ooty was severely damaged. This is the district's major rain disaster after the 1978 landslide. Smaller landslides and fallen trees block parts of the road as well, however. Houses have been damaged, communication infrastructure has come down, and roads and railroads have disintegrated. There is unprecedented extent of damage to infrastructure (Ganapathy and Rajawat 2015; Edison et al. 2016). The approach road from
Ooty through Coonoor to Mettupalayam was severely damaged.. Most of the landslides took place along the National Highways upslopes, Burliar-Ooty and few of them took place on the way to Coonoor-Kundah road. 68 fall in built-up areas out of 89 landslides. The deaths reported were 13, 23 and 9 in talks in Ooty, Coonoor and Kotagiri. Approximately 1890 houses completely or partially damaged due to the landscape and the estimated total losses are worth about USD 6 million (The Hindu 2009). The year wise details of landslides occurred in the district and their damage consequences are listed in the Table 1 . From the review of literatures it has been clearly revealed that most of the landslides in The Nilgiris are triggered by the intense rainfall, human and cultural activities, the toe of the slope was removed for laying roads without any engineering measures, and unauthorized buildings gave additional weight on top of the slope.

\section{Methodology}

Landslide hazard assessment is an important measurement for risk management and land use planning for areas prone to landslides. The landslide hazard zonation maps are not only useful for monitoring landslides and

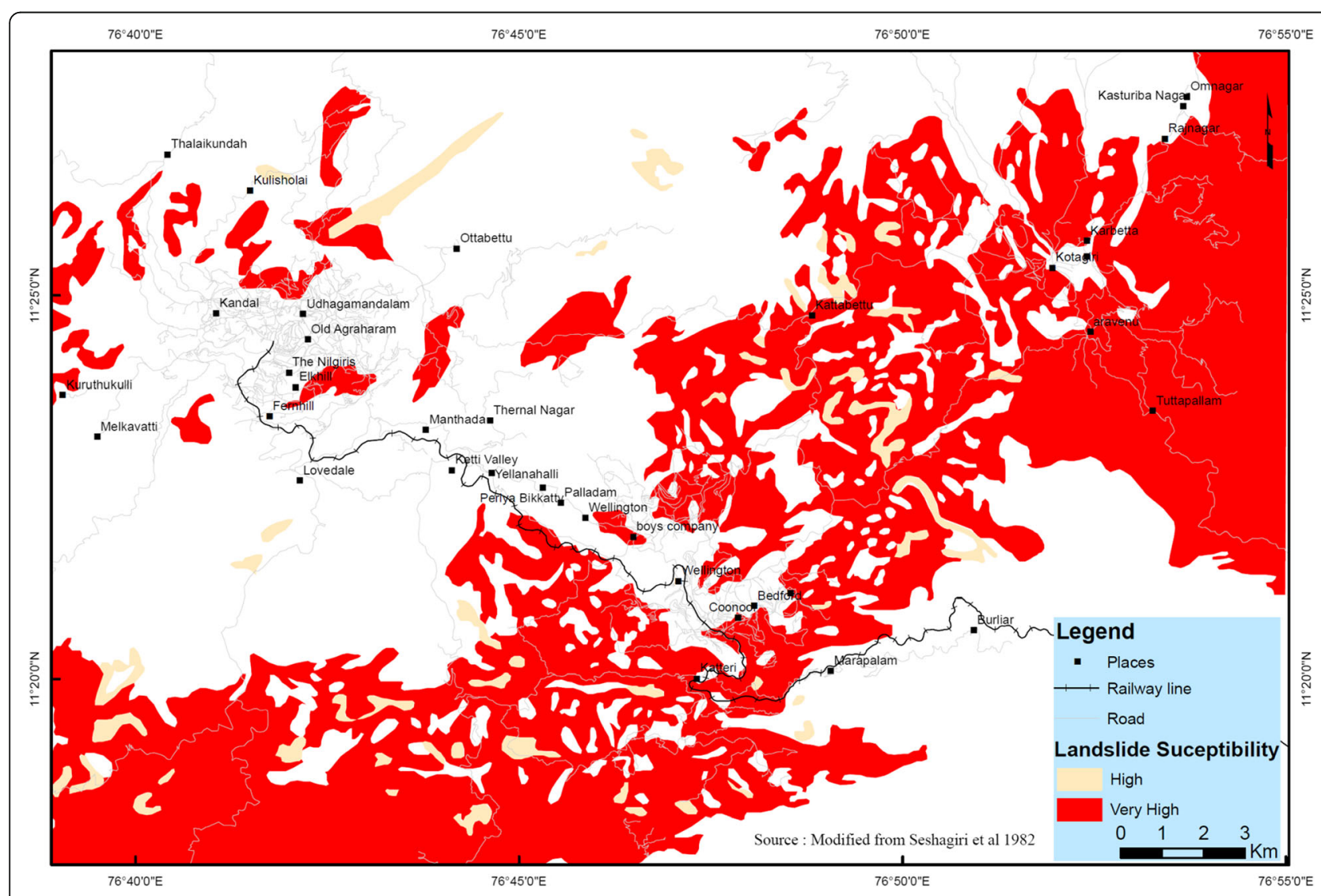

Fig. 2 Detailed landslide hazard zonation map of Nilgiris carried out in 1980"s 
also helpful in predicting future slope failures in a region (Pardesi et al. 2013). Number of landslide hazard assessment studies carried out for The Nilgiris district from the year 1979. Tamil Nadu's government launched detailed geological investigations of the landslides in August 1979, in collaboration with the State Geology branch, the Geological Survey of India (GSI). The landslide susceptibility map (Fig. 2) was first produced in India on a regional scale for the district of The Nilgiris (Seshagiri et al. 1982) The process of preparing a macroscale map of the landslide hazard map is predominantly a technique of numerical superimposition. India's Geological Survey studied the 1993 landslides in The Nilgiris. About 408 landslides / slips have been reported during this year and the serious one is Marappalam Landslide, resulting in 27 deaths. A detailed geological and geotechnical report prepared on this by GSI (Balachandran et al. 1996).

Ramakrishnan et al. (2002) carried out a study on using aerial photos and ortho photos, thematic layers were prepared in a GIS platform. They have brought out a landslide hazard zonation map of Kotagiri, which is northwestern part of The Nilgiris district. Rajarathnam and Ganapathy (2006) brought out landslide hazard zonation map of south India using remote sensing GIS techniques in 1:6 Million scale and divided the areas in to four categories viz., low, moderate, high and very high. Also they have narrated the significance of the each zone on landuse regulations in a simple table. Thanavelu and Chandrasekaran (2008) undertaken detailed geotechnical investigations on November 2006 landslides of The Nilgiris district, they have documented numerous landslides. A study on landslide susceptibility mapping for part Ooty town carried out by Rajkumar et al. (2007) based on conventional Delphi Exercise. The effect of deforestation on landslides in the part of The Nilgiris was studied by Vasantha Kumar and Bhagavanulu (2007). A first level landslide risk mapping was carried out using socio economic data by Ganapathy and Jothimani (2009). Chandrasekaran (2010) studied the damage induced by the rainfall trigged landslides of November 2009 landslides in The Nilgiris district. He had discussed the different type of structural failures caused by landslides. Ganapathy et al. (2010) insisted the need and urgency of landslide risk planning for The Nilgiris and risk posed to urban settlements.

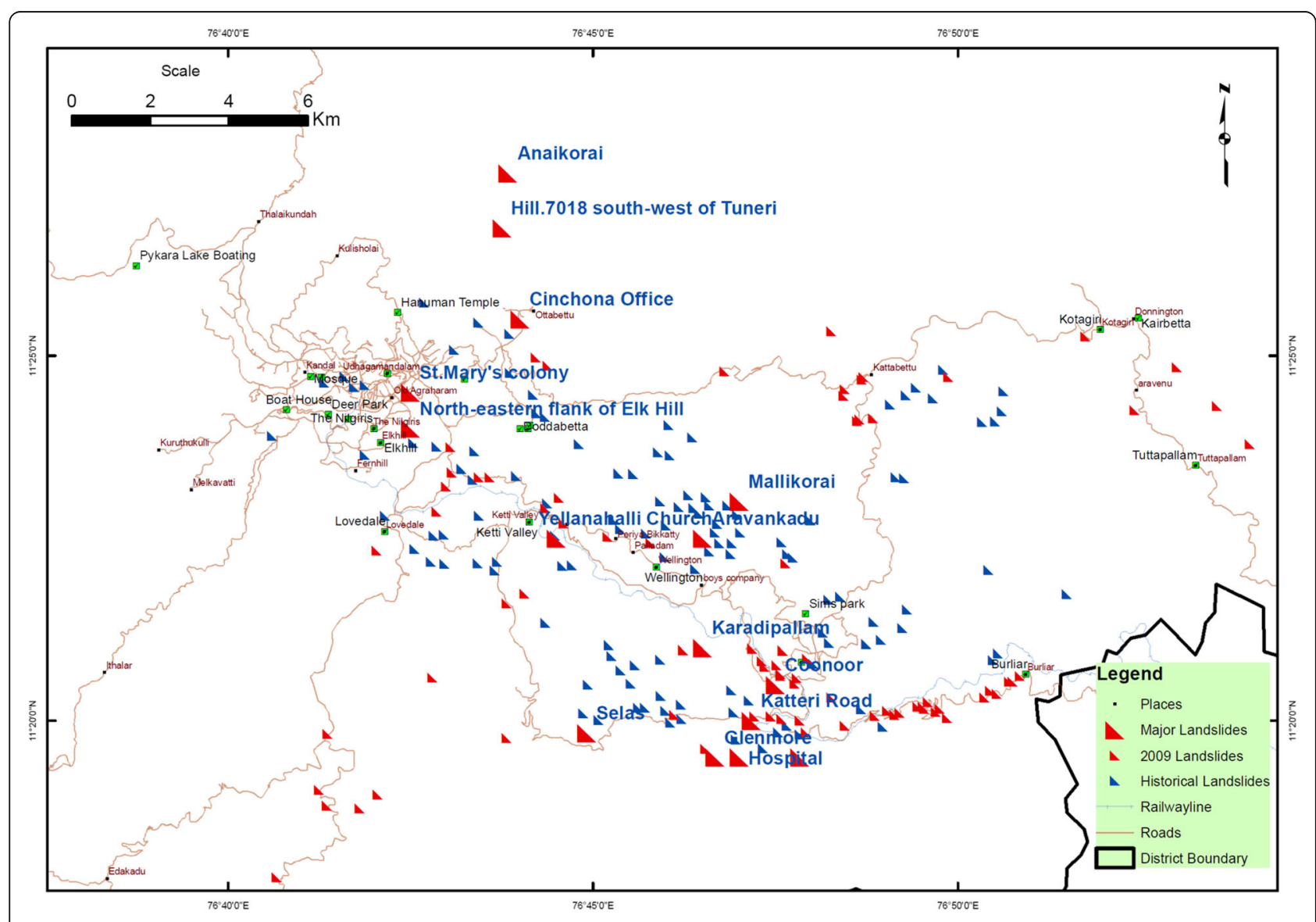

Fig. 3 Spatial location of landslides from Mettupalayam to Ooty 
Naveen Raj et al. (2011) quantitatively determined the landslide hazard zonation using the relative effect method in southeastern part of The Nilgiris and compared the various thematic layers viz., geology, geomorphology, landuse, slope, lineament density, drainage density, distance to drainage, and soil with landslide inventories and classified the area in to 5 different categories viz., very low, low, moderate, high, and very high. The problem related to environmental societal issues in connection with landslide hazard mitigation practices was assessed by Ganapathy and Hada (2012). This was the first attempt in The Nilgiris. The use of soil bio engineering was strongly insisted to stabilize the slope of the The Nilgiris district. The pattern and nature of landslide occurrences, geological process involved in triggering landslides are discussed by Manimaran et al. (2012). Regional level hazard zonation and vulnerability analysis for road network was carried out by Vaani and Sekar (2012) for southwestern the part of The Nilgiris. Analytical Hierarchy Process was used in GIS to produce landslide hazard zonation by integration of thematic layers which contribute to landslide. An attempt was made by Antony and Mohd (2012) on identification of landslide prone zones in Ooty region using W-4 system of $2 \mathrm{D}$ electrical resistivity imaging technique. They have identified the subsurface profile for four different sites at The Nilgiris district. Pradeep Kishore et al. (2012) used the geotechnical parameters to understand the slope instability by limit equilibrium method in application of Landslide Susceptibility Analysis. The factors of safety for 22 different slopes were calculated based on the soil analysis. The combined use of socio economic, remote sensing and GIS data for landslide hazard mapping using Artificial Neural Network was carried out by Prabu and Ramakrishnan (2012) for The Nilgiris. Chandrasekaran et al. (2013) carried out finite element for three landslide affected slopes in The Nilgiris and studied the infrastructural damages caused by the November 2009 landslides. Jaiswal and van Westen (Jaiswal and Van Westen 2012 \& Jaiswal and Van Westen 2013) carried out an in-depth study on hazard, vulnerability and risk assessment for rainfall induced landslides in transportation corridors from Burliar to Coonoor. This is the only detailed study so far available for risk assessment landslides in The Nilgiris. The direct and indirect risk as well as the rainfall threshold for different slopes was developed. Weighted overlay analysis was used to assess the landslide hazard zones in GIS by Muthukumar (2013). Sunandana and Lakshmikanta (2013) used image processing technique and Digital Elevation Model to identify landslide hazard prone area in GIS. An attempt was made by Gurugnanam et al. (2013) on compilation of landslide location details from various literatures using GIS. The landslide locations of The Nilgiris were collected from different literatures and geo-referenced the locations in GIS platform. The spatial locations were generated by

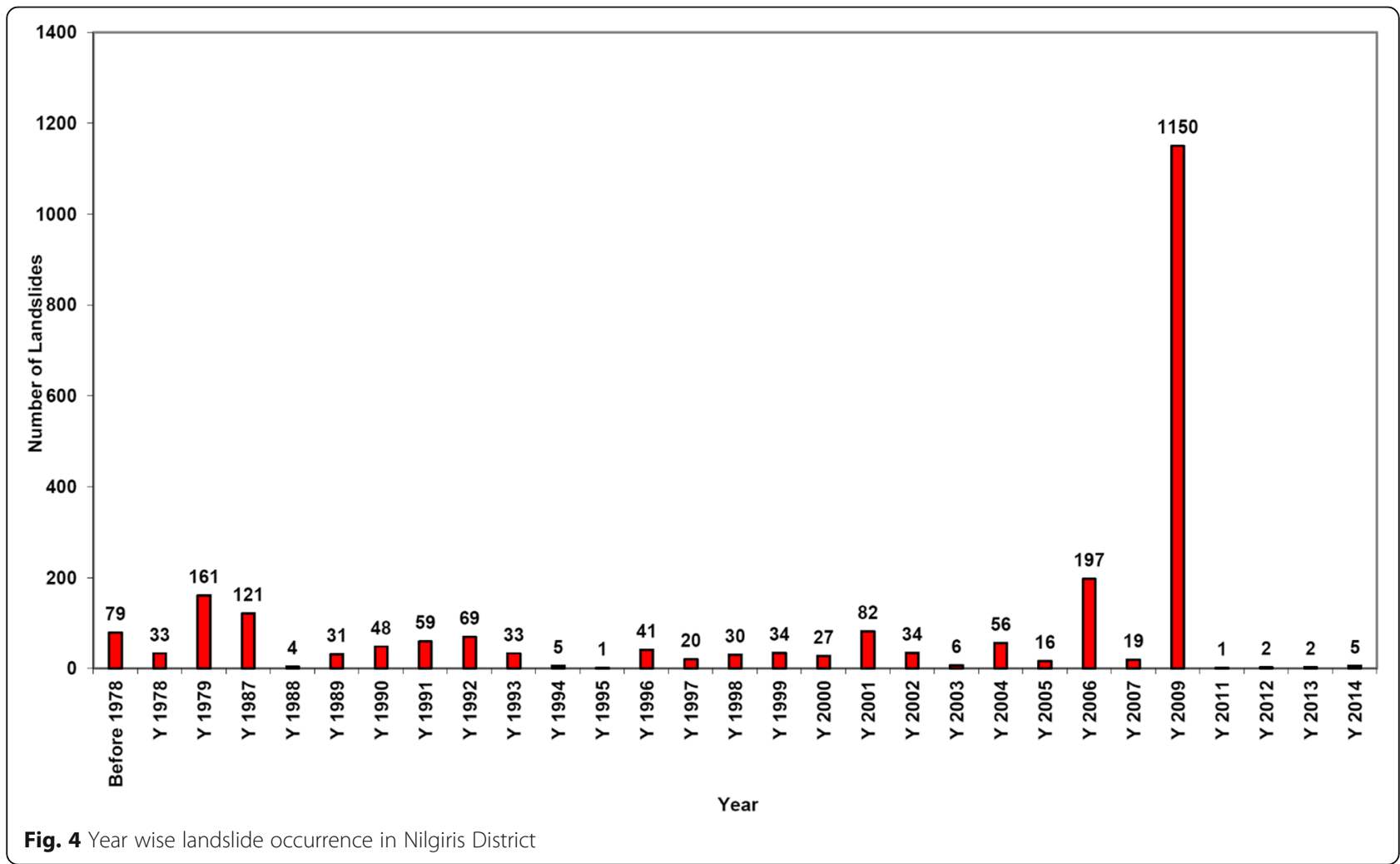


digitization tool and the coordinates were extracted by geometry tool. The land use and land cover changes were compared for two different years and they concluded that the landuse for tea estates without considering proper drainage and slope ultimately results in loss of natural eco system and ends in massive frequent landslips. The influences of landuse and land cover on landslides were studied by Bairavi et al. (2014). Nalina et al. (2014) analyse the slope stability using geotechnical parameters for the road sector from Kallar to Coonoor sectors. They used the Artificial Neural Network (ANN) in MAT LAB to train the data set and concluded that the Backward Propagation - ANN technique give good prediction value. Ganapathy and Rajawat (2015) documented the use of hazard and vulnerability maps in particular with land use practice in landslide prone areas. Gobinath et al. (2015) studied the link between soil root and landslides in connection with slope stabilization in The Nilgiris district. Based on the review of landslide studies in the Nilgiri district it can be grouped in to three categories viz., i) landslide hazard/ susceptibility zonation mapping using Remote sensing \& GIS and different computational methods ii) detailed geotechnical investigation and structural analysis on landslide and its damage iii) use of landslide studies in Landuse regulations and disaster preparedness. However there is no updation of hazard zonation map after the year 1980 .

\section{Results and discussion}

Predicting future landslide in an area needs understanding of the condition of the geological process and the nature of landmass. There are varieties of factors associated with landslide activity in any area such as past landslides and their distribution, bedrock, slope steepness or inclination, hydrologic factor, human effects. Among these the inventory of past landslides plays a major role (OAS/DRDE 2007). A map of existing landslides serves as the data source for understanding conditions controlling to landslide occurrences. Interpreting the likely hood of future landslides occurrences requires an understanding of condition and process controlling past landslides in the area of interest (OAS/DRDE 2007). Landslide inventory analysis can be done by various methods such as i) landslide distribution maps based on image interpretation (event based inventories) ii)

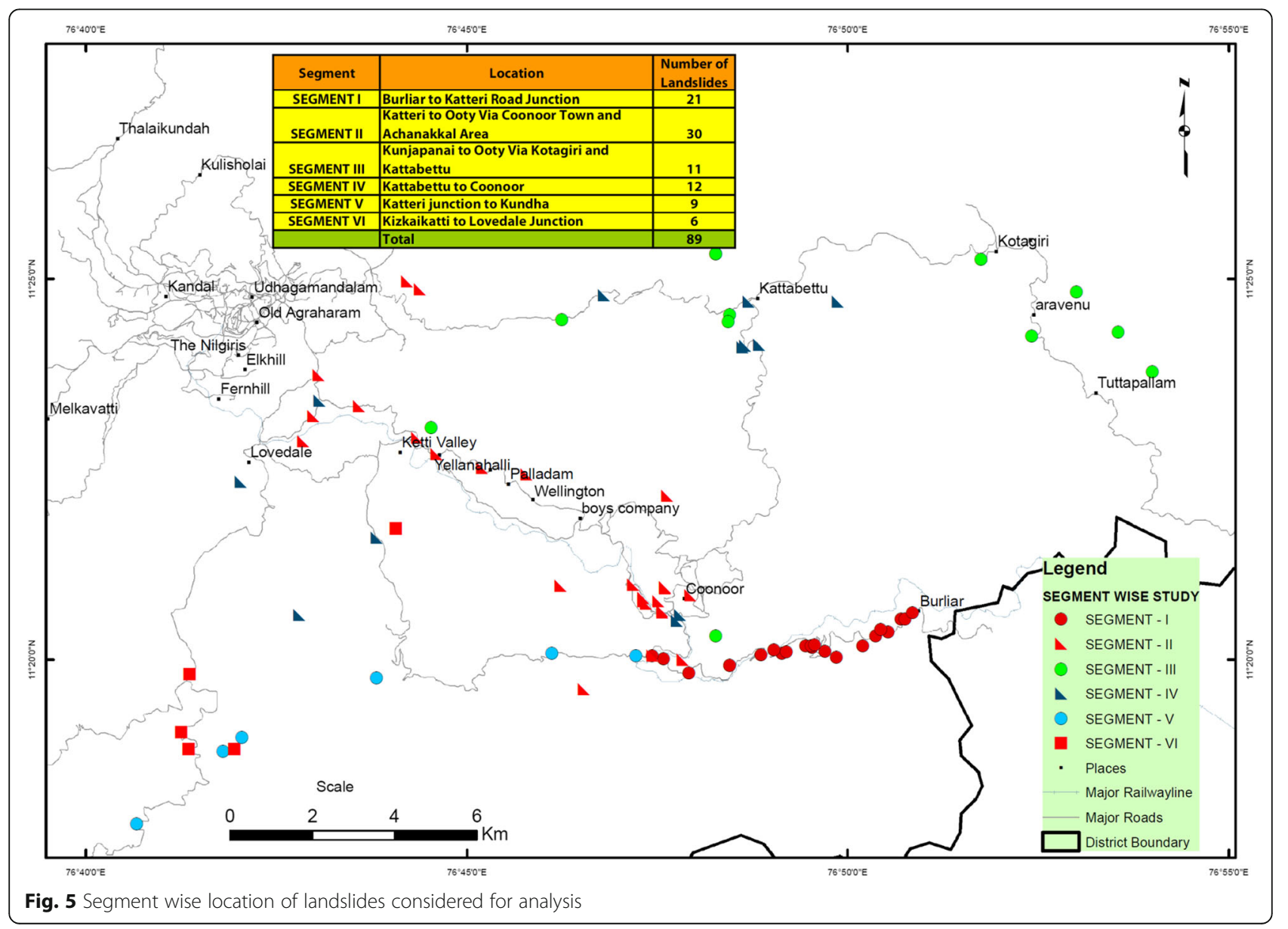


landslide activity maps based on multi temporal image interpretation iii) generating inventories based on historical records iv) inventory based on radar interferometry, v) representation of landslide inventory as density information, landslide isopleth maps (Wieczorek 1984; Crozier 2005; Keefer 2002; Reid and Page 2003; Guzetti et al. 2000 \& 2005; Jaiswal and van Westen 2009; Squarzoni et al. 2003; Colesanti and Wasowski 2006; Coe et al. 2000; Bulut et al. 2000; Valadao et al. 2002).

Even though many researchers carried out research on landslide in Nilgiri district there is no fully or fairly documented landslide inventory for the district. To update the existing data, a detailed inventory on past and recent landslides was collected and a GIS based database was created. Historical landslide information were collected from various agencies viz., Geological Survey of India (1824-1993), Railways records (1994-2006), Media and News paper (2007-2008; 2010-2014), Geotechnical Cell, Coonoor, limited field checks (2009). Totally 3453 landslide details were collected, out of this only 414 landslides were spatially documented (Fig. 3) and the year wise landslide incidences are presented in (Fig. 4). However most of the landslide inventories don't have detailed information for further analysis. Out of this 89 landslides occurred in the year 2009 have more details segment wise such as coordinates, dimensions, type of slide, history, material involved, area of landslide occurrence, structures affected by the landslide, causalities caused by the landslides, cause, existing remedial measures etc (Fig. 5).

Landslide triggering factors are varying from region to region based on the different terrain condition and different parameters. Various knowledge driven methods recommended by researchers landslide susceptibility assessment viz., geomorphological mapping, direct mapping methods, multiclass weigh methods, spatial multicriteria analysis, Analytical Hierarchy Process and Fuzzy logic approach (Lee 2005; Yin and Yan 1988; Van Westen 1993; Suzen and Doyuran 2004; Chung and Fabbri 1993; Luzi 1995; Carrara 1983; Gorsevski et al. 2000; Lee et al. 2004; Ermini et al. 2005; Kanungo et al. 2006). Landslide Hazard Assessment needed a multi hazard approach as different type of landslide may occur, each with different characters \& causative factors and spatial, temporal and size probability (Guzzetti et al. 2005).

To understand the regional hazard initially the Building Materials and Technology Promotion Council

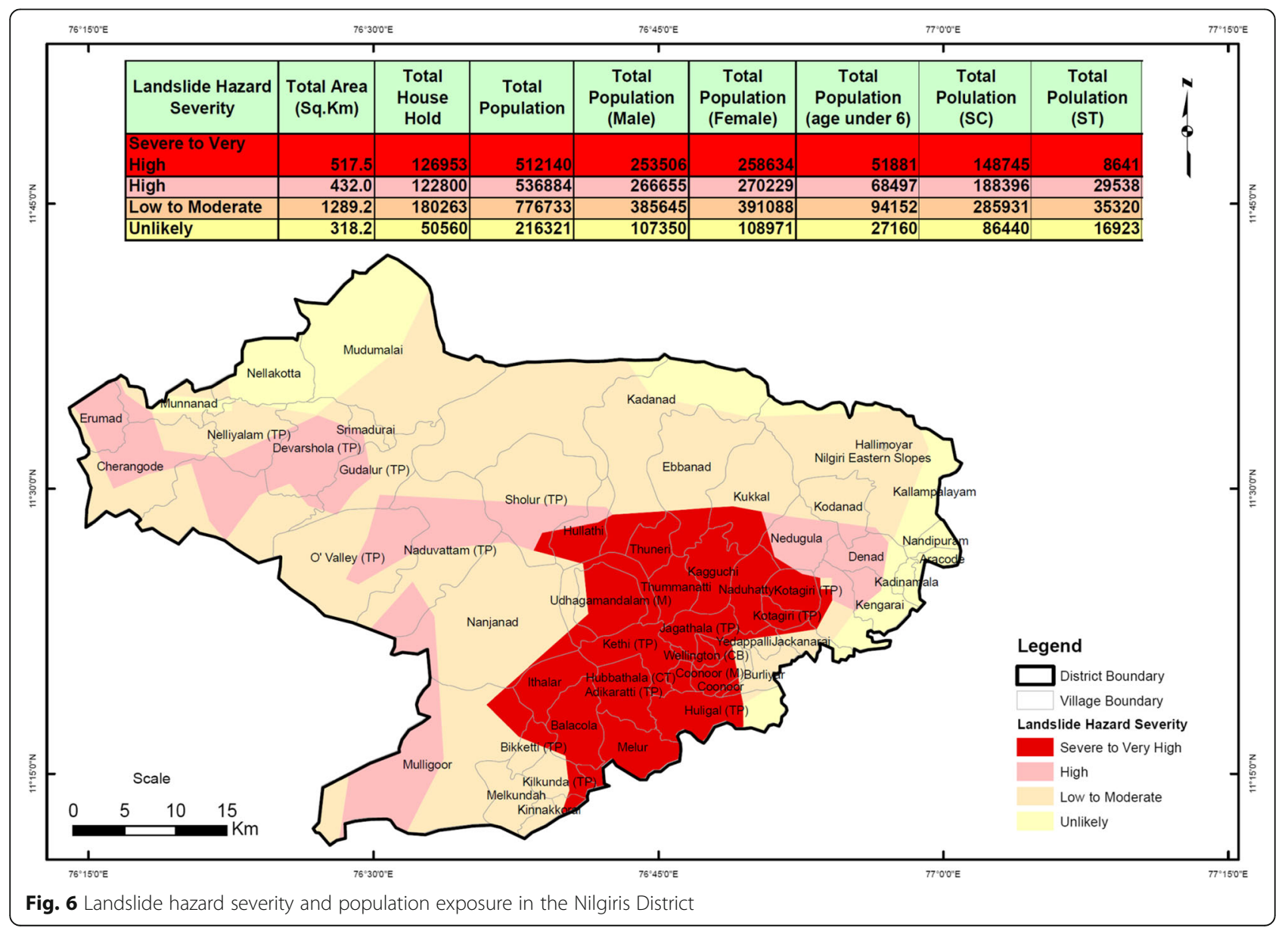


(BMTPC) methodology for large scale mapping is used. The landslide hazard zonation Map of India presented in the Landslide Atlas 2003 is based on a systematic study of the literature, information available on intensity and spatial distribution of landslides, preparation and processing of thematic maps at small scale of 1:6 million on a GIS platform (BMTPC 2002). To understand the district level severity of landslide hazard for The Nilgiris district, a study has been carried out using various thematic maps viz. Geology (3) - 12\%, Slope (10) - 40\%, Landuse (9) - 36\%, Rainfall (3) - 12\% using Analytical Hierarchy process. Using this landslide hazard zonation map was prepared and the hazard wise landslide severity is calculated and presented in Fig. 6. This map will be useful for only regional studies and for quick socio economic risk assessment for The Nilgiris district.

The landslide hazard map prepared by GSI in the year 1982 at small scale based on numerical superimposition technique using thematic layers such as geology, slope, land use, geomorphology, rainfall etc. and the resultant map shows different severity of landslide hazards and none of them revised this map. Since most of the thematic factors are same for the region it was planned to revise the hazard area based on the impact of the landslides coupled with existing hazard maps directly by using additional information's viz., the road, railway network and the latest landslide locations were used in GIS platform (Fig. 7). However the resultant areas are very vast and a site specific slopes were identified as major hot spots by incorporating size, volume of debris, reactivation of landslides, built up area, fatalities etc.,. Based on the Analysis totally 28 landslide hot spot locations (Fig. 8 and Table 2) were considered as most vulnerable locations in The Nilgiris district. By using documented landslides the updated landslide inventory map of the district is presented in the Fig. 9.

\section{Conclusion}

Landslide hazard information provide as one of the many components in an integrated development planning study (OAS/DRDE 2007). The landslides are differing from place to place and based on the nature of study area and its environment. The hazard zonation studies should keep in mind that depending upon the need the scale and map unit will vary in place to place (Corominas et al. 2014). Even though the history of landslides

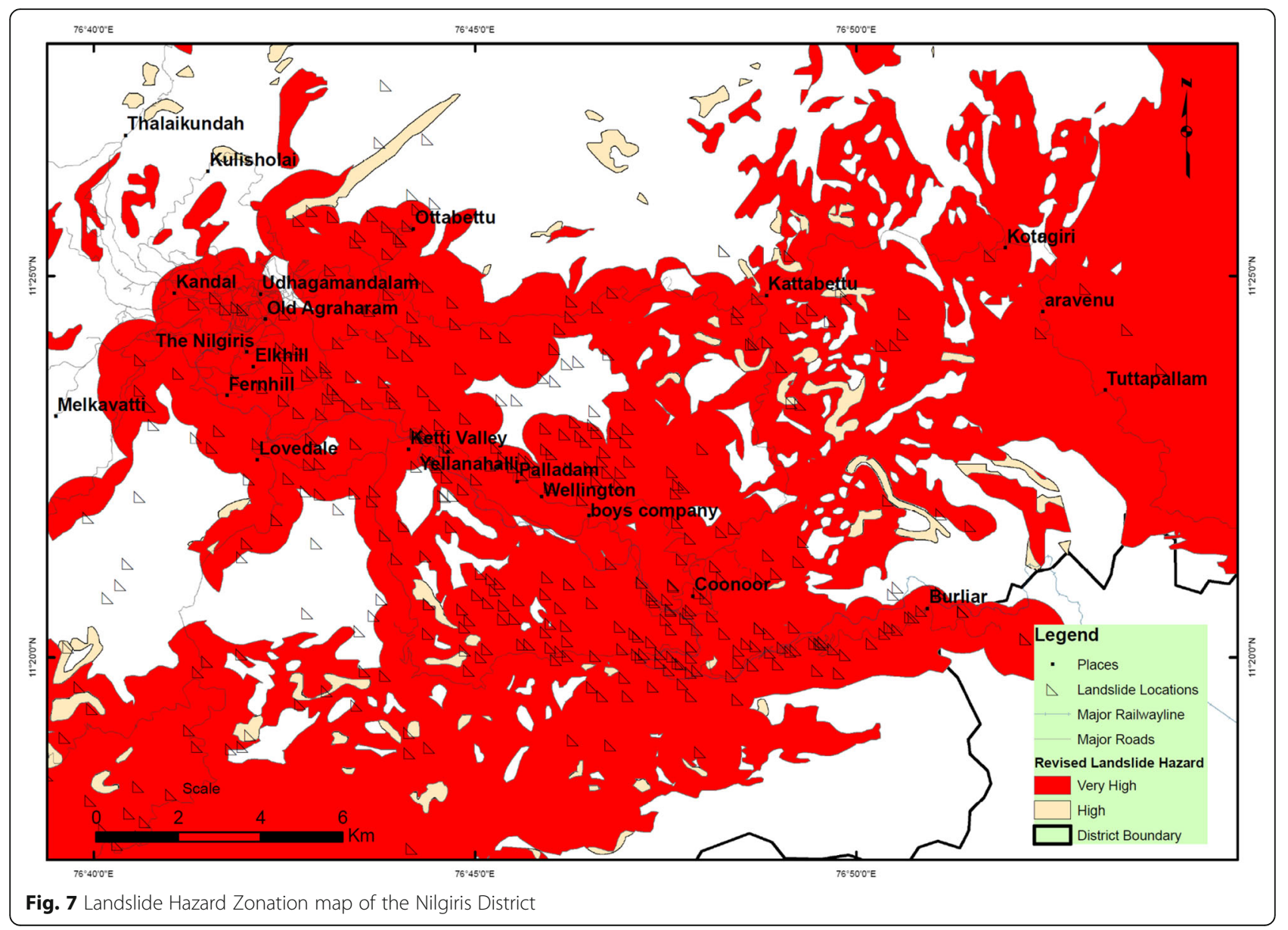




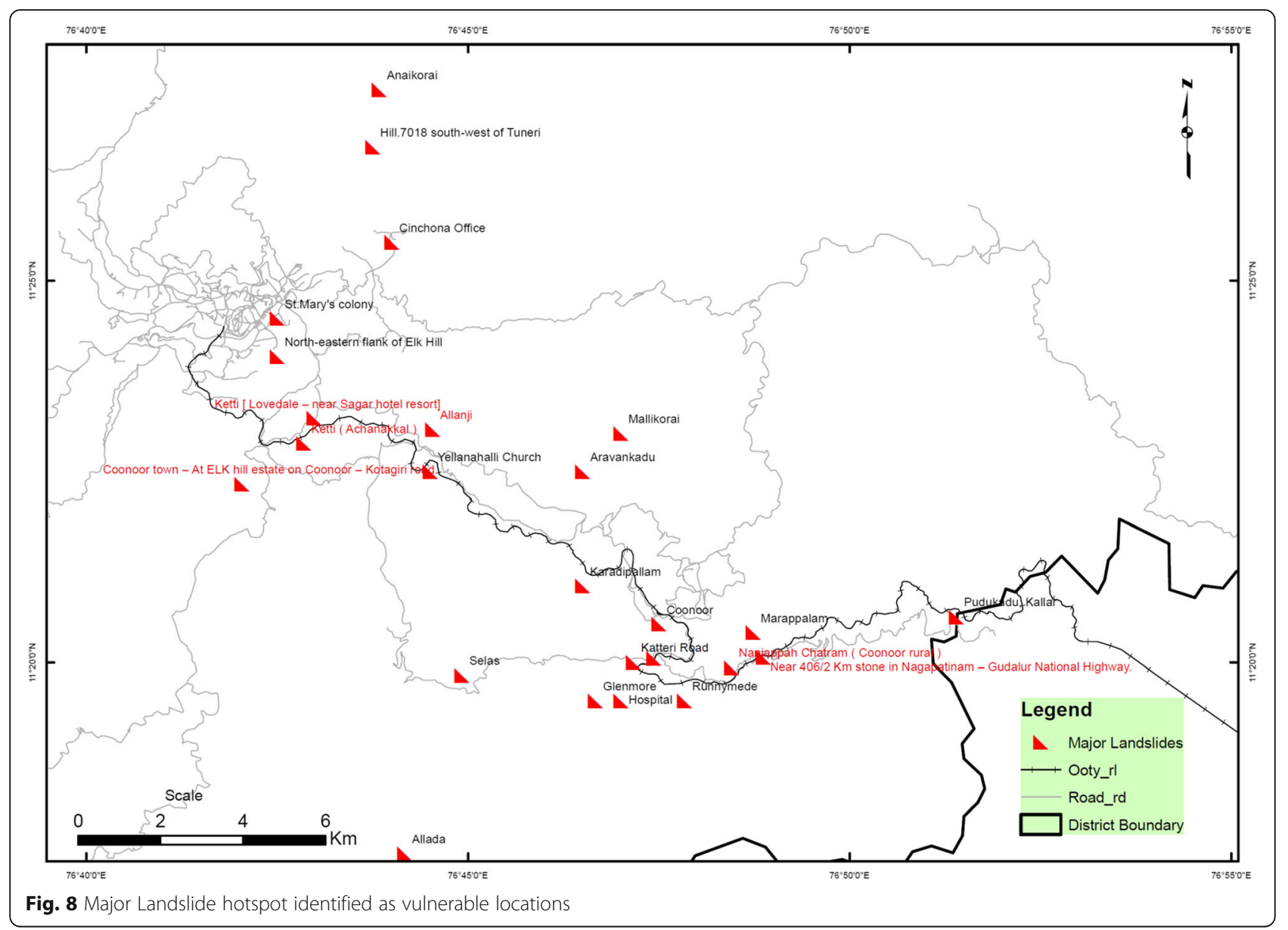

Table 2 Major Landslide Hotspots selected

\begin{tabular}{|c|c|c|c|c|c|}
\hline SI.No & Location & Year & SI.No & Location & Year \\
\hline 1. & Katteri Road & 1979 & 2. & Runnymede & 1979 \\
\hline 3. & Aravankadu & 1979 & 4. & Hospital & 1979 \\
\hline 5. & Doddakombai & 1979 & 6. & Glenmore & 1979 \\
\hline 7. & Allada & 1979 & 8. & Coonoor & 1979 \\
\hline 9. & Selas & 1979 & 10. & Karadipallam & 1979 \\
\hline 11. & Mallikorai & 1979 & 12. & Marappalam & 1993 \\
\hline 13. & St.Mary's colony & 1979 & 14. & Pudukadu, Kallar & 2006 \\
\hline 15. & Dunsdale - Somarsdale & 1979 & 16. & Allanji & 2009 \\
\hline 17. & Cinchona Office & 1979 & 18. & Nanjappah Chatram (Coonoor rural) & 2009 \\
\hline 19. & $\begin{array}{l}\text { Hill.7018 south-west of } \\
\text { Tuneri }\end{array}$ & 1979 & 20. & $\begin{array}{l}\text { Coonoor (Municipal limit) Coonoor- Mettupalayam road upslope near Katteri Railway } \\
\text { bridge. }\end{array}$ & 2009 \\
\hline 21. & North-eastern flank of Elk Hill & 1979 & 22. & Near 406/2 Km stone in Nagapatinam to Gudalur National Highway. & 2009 \\
\hline 23. & Yellanahalli Church & 1979 & 24. & Coonoor town at ELK hill estate on Coonoor to Kotagiri road. & 2009 \\
\hline 25. & Anaikorai & 1979 & 26. & Ketti (Achanakkal). & 2009 \\
\hline 27. & Porthimund Dam & 1979 & 28. & Ketti [Lovedale - near Sagar hotel resort]. & 2009 \\
\hline
\end{tabular}




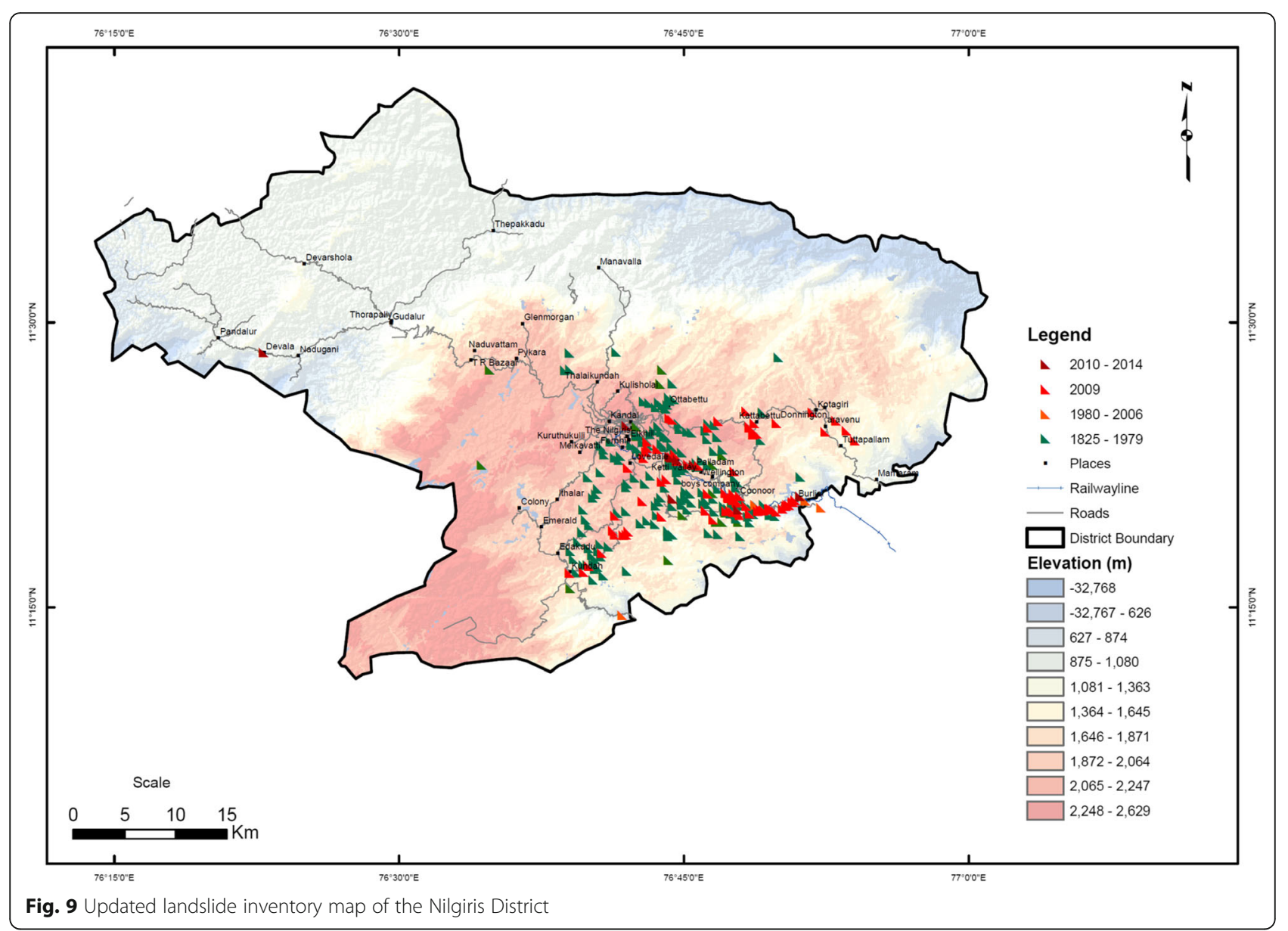

recorded in early 1800's the detailed landslide studies in The Nilgiris started in late 1970's only. Later many researchers carried out work on landslide hazard zonation studies. However the work carried out by Geological Survey of India (GSI) in association with State Geology of Mines in the year 1982 is the more authenticated in detailed study at 1:12500 Scale and full-fledged work for The Nilgiris district. Even though many landslides occurred in The Nilgiris district there is no much loss on life compare to the other parts of India. The 2009 landslides of the district have created more damage to infrastructure and this can be considered as major landslide disaster after 1978 \& 1979. The present study on landslide inventory and damage consequences are the detailed catalogue one for landslide inventory concern. Only one study carried out by the authors towards early warning system for the landslides in the district and that too not published. The study for The Nilgiris district clearly reveals that even though many studies carried out on hazard zonation level however there is no detailed study on prediction of landslides. The landslide hazard zonation maps should be used properly and there should be a detailed investigation on individual slopes which is prone to landslides. It should include detail maps in large scale at planning level which can show development, existing landslide scars, and predicted new slopes where we can deploy the early warning system. The future researchers can focus on landslide initiation susceptibility maps which focus on whether the geological, topographical, geotechnical and climatic conditions really contributing for slope failure based on past landslide locations. Also an investigation of slope stability in connection with the developmental activity should be investigated for future probable slope failure areas in The Nilgiris district. There is no early warning system followed in The Nilgiris district as per the study and one of the landslide related focus area for this district is development of landslide early warning systems. Guidelines can be prepared for assessing and planning policy and consent requirement for landslide prone lands in The Nilgiris district.

\section{Acknowledgements}

Dr. A.S. Rajawat, Group Head, SAC, ISRO and Dr. S.S. Chandrasekaran, Professor, School of Civil Engineering is acknowledged for their timely support and encouragements. Technical discussion with Mr. Thanavelu, Sr. Geologist, and Dr. Pankaj Jaiswal from GSI are gratefully acknowledged. The 
first and second authors are thankful to Dr. G. Viswanathan, Chancellor at VIT University, Vellore, India, who provides all the facilities and his encouragement about this work.

\section{Authors' contributions}

The first author carried out the research and mapping, drafting of the manuscript, editorial and finalization of corrections. The second author contributed to literature sourcing, mapping, editorial and structure review. Both authors read and approved the final manuscript submitted.

\section{Authors' information}

Not Applicable.

\section{Funding}

The present study is the part of Indian Space Research Organization (ISRO), ongoing project-ISRO/RES/4/611/13-14. The authors are thankful to SAC, ISRO, Government of India for funding under RESPOND programme.

\section{Availability of data and materials}

Not Applicable.

\section{Competing interests}

The authors declare that they have no competing interests.

Received: 14 May 2019 Accepted: 23 December 2019

Published online: 06 January 2020

\section{References}

Antony RA, Mohd AKPH (2012) Prediction and control of landslide using w-4 system - 2D electrical resistivity imaging technique in Pudukadu, Ooty, the Nilgiris. J Asian Res Publishing Netw 1:42-47

Antony RA, Ramanujan N (2012) Palaeoscars and landslide prediction using 2D ERI techniques in Ooty area, Nilgiri district, Tamil Nadu. Arch Appl Sci Res 4: 262-268

Arogyaswamy RNP (1967) Geomorphological features of the Nilgiris mountains. Proceeding Seminar on Geomorphological studies. Saugor University, India, pp 78-86

Bairavi S, Muthukumar M, Gurugnanam B, Arunkumar M (2014) Assessment of influenciable landuse/landcover for landslides study - a remote sensing and GIS approach. Int J Remote Sensing Geo Sci 3:11-14

Balachandran V, Thanavelu C, Pitchaimuthu R (1996) Marappalam landslide, The Nilgiris district, Tamil Nadu, India - A case study. Proceeding of International Conference on Disaster and Mitigation, vol 1. Anna University, Chennai, pp $21-28$

BMTPC (2002) Landslide Hazard zonation atlas of India, published by building materials and technology promotion council. Government of India and Anna University, Chennai, $125 \mathrm{p}$

Bulut F, Boynukalin S, Tarhan F, Ataoglu E (2000) Reliability of landslide isopleth maps. Bull Eng Geol Environ 58:95-98

Carrara A (1983) Multivariate models for landslide Hazard evaluation. J Math Geol 15:403-426

Chandrasekaran SS (2010) Assessment of damages induced by recent landslides in Ooty, Tamil Nadu. Indian Geotechnical Conference, GEOtrendz, IGS Mumbai Chapter \& IIT Bombay. Indian Geotechnical Society, New Delhi, pp 687-688

Chandrasekaran SS, Sayed Owaise R, Ashwin S, Rayansh Jain M, Prasanth S, Venugopalan RB (2013) Investigation on infrastructural damages by rainfallinduced landslides during november 2009 in Nilgiris, India. J Nat Hazards 65: 1535-1557

Chung CF, Fabbri AG (1993) Representation of geoscience data for information integration. J Non-Renewable Resources 2:122-139

Coe, J.A., Michael, J.A., Crovelli, R.A., and Savage, W.Z., 2000, Preliminary map showing landslide densities, Mean Recurrence Intervals, and Exceedance Probabilities as Determined from Historic Records, Seattle, Washington doi: https://doi.org/10.3133/ofr00303

Colesanti C, Wasowski J (2006) Investigating landslides with space-borne synthetic aperture radar (SAR) interferometry. J Eng Geol 88:173-199

Corominas J, Van Westen CJ, Frattini P, Cascini L, Malet JP, Fotopoulou S, Pitilakis K (2014) Recommendations for the quantitative analysis of landslide risk. Bull Eng Geol Environ 73:209-263
Crozier MJ (2005) Multiple occurrence regional landslide events in New Zealand: hazard management: an overview. J Eng Geol 64:65-87

Edison T, Ganapathy GP, Chandra Sekaran SS, Rajawat AS (2016) Use of GIS in assessing building vulnerability for landslide hazard in the Nilgiris, Western Ghats, India. J Int Soc Prev Mitigation Nat Hazards 82:1031-1050

Ermini L, Catani F, Casagli N (2005) Artificial neural networks applied to landslide susceptibility assessment. Geomorphology 66:327-343

Ganapathy GP, Dharma R, Sekar SK (2012) Assessing spatial vulnerability for landslide threat in hilly areas of Nilgiris, Tamil Nadu, India, international symposium on mountain resource Management in a Changing Environment. Kathmandu University, Nepal

Ganapathy GP, Hada CL (2012) Landslide hazard mitigation in the Nilgiris district, India - environmental and societal issues. Int J Environ Sci Dev 3:497-500

Ganapathy, G.P., and Jothimani, P., 2009, Hazard estimation and first level landslide risk mapping-a case study, Burliar area of the Nilgiris district in Western Ghats, Abstracts of the "Geomatics 2009" National Conference, Dehradun, p. 4-6

Ganapathy GP, Mahendran K, Sekar SK (2010) Need and urgency of landslide risk planning for Nilgiri district, Tamil Nadu state, India. Int J Geomatics Geosci 1: 29-40

Ganapathy GP, Rajawat AS (2015) Use of hazard and vulnerability maps for landslide planning scenarios: a case study of the Nilgiris, India. J Nat Hazards 77:305-316

Gobinath R, Ganapathy GP, Raja Prakash R, Prasath R, Raja P (2015) Studies on soil - root stabilisation for slope protection - a study using some grass varieties from Nilgiris district. Int J Earth Sci Eng 8:1526-1531

Gomathi R, Ram Mohan V, Backiaraj S (2013) Landslide susceptibility zonation in Kavithole and Kukalthurai halla watershed in northern part of Nilgiris district. Int J Geomatics Geosci 4:366-378

Gorsevski, P.V., Gessler, P., and Foltz, R.B., 2000, Spatial prediction of landslide hazard using discriminant analysis and GIS. GIS in the Rockies 2000 Conference and workshop: applications for the 21st century, Denver, Colorado $25-27$

Gurugnanam B, Arunkumar M, Venkatraman ATVR, Bairavi S (2013) Assessment on landslide occurrence: a recent survey in Nilgiri, Tamil Nadu, India. Int J Sci Environ Technol 2:1252-1256

Guzzetti F, Cardinali M, Reichenbach P, Carrara A (2000) Comparing landslide maps: a case study in the upper Tiber River basin, Central Italy. J Environ Manag 25:247-363

Guzzetti F, Reichenbach P, Cardinali M, Mirco G, Francesca A (2005) Probabilistic landslide hazard assessment at the basin scale. Geophysics J Roy Astronomy Soc 72:272-299

GSI (1982), District Resource Map Series: Nilgiri District Tamil Nadu published by Geological Survey of India-explanatory Note. p 1.

Jaiswal P, Van Westen CJ (2009) Probabilistic landslide initiation hazard assessment along a transportation corridor in the Nilgiri area, India. Geophysical Research Abstracts, 11:EGU2009-2854, EGU General Assembly, Vienna, Austria, p. 2854. http://meetings.copernicus.org/egu2009. Accessed 18 Nov 2018

Jaiswal P, Van Westen CJ (2012) Frequency-size relation of shallow debris slides on cut slopes along a railroad corridor: a case study from Nilgiri hills, southern India. J Nat Hazards 61:1263-1275

Jaiswal P, Van Westen CJ (2013) Use of quantitative landslide hazard and risk information for local disaster risk reduction along a transportation corridor: a case study from Nilgiri district, India. J Nat Hazards 65:887-913

Jaiswal P, Van Westen CJ, Jetten V (2010a) Quantitative assessment of direct and indirect landslide risk along transportation lines in southern India. Nat Hazards Earth Sys Sci 10:1253-1267

Jaiswal P, Van Westen CJ, Jetten V (2010b) Quantitative landslide hazard assessment along a transportation corridor in southern India. J Eng Geol 116 236-250

Jaiswal P, Van Westen CJ, Jetten V (2011a) Quantitative assessment of landslide hazard along transportation lines using historical records. J Landslides 8:279-291

Jaiswal P, Van Westen CJ, Jetten V (2011b) Quantitative estimation of landslide risk from rapid debris slides on natural slopes in the Nilgiri hills, India. Nat Hazards Earth Syst Sci 11:1723-1743

Kanungo DP, Arora MK, Sarkar S, Gupta RP (2006) A comparative study of conventional, ANN black box, fuzzy and combined neural and fuzzy weighting procedures for landslide susceptibility zonation in Darjeeling Himalayas. J Eng Geol 85:347-366

Kanungo DP, Arora MK, Sarkar S, Gupta RP (2009) Landslide susceptibility zonation (LSZ) mapping - a review. J South Asia Disaster Stud 2:81-105 
Keefer DK (2002) Investigating landslides caused by earthquakes - a historical review. Surv Geophys 23:473-510

Lee S (2005) Application of logistic regression model and its validation for landslide susceptibility mapping using GIS and remote sensing data. Int J Remote Sens 26:1477-1491

Lee S, Ryu J-H, Won J-S, Park H-J (2004) Determination and application of the weights for landslide susceptibility mapping using an artificial neural network. J Eng Geol 71:289-302

Luzi L (1995). Application of favourability modeling to zoning of landslide hazard in the Fabriano area, central Italy, Proc. Joint European Conference and Exhibition on Geographic Information, JEC-GIS'95: From Research Application Through Cooperation, Den Haag, The Netherlands, pp. 398-40

Manimaran G, Antony RA, Selvam S, Manimaran D, Sugan M (2012) Characterization and disaster management of landslides in the Nilgiris mountainous terrain of Tamil Nadu, India. Int J Geomatics Geosci 3:1-12

Muthukumar M (2013) GIS based geosystem response modeling for landslide vulnerability mapping parts of Nilgiris, South India. Disaster Adv 6:58-66

Nalina P, Meenambal T, Sathyanarayan SR (2014) Slope stability analysis of KallarCoonoor hill road stretch of the Nilgiris. J Comput Sci 10:1107-1114

Naveen Raj T, Ram Mohan V, Backiaraj S, Muthusamy S (2011) Landslide hazard zonation using the relative effect method in south eastern part of Nilgiris, Tamil Nadu, India. Int J Eng Sci Technol 3:3260-3266

OAS/DRDE., 2007, Landslide Hazard Assessment, Nature Hazard Primer - Part III, Chapter 10-1, p. 1-32

Pardesi SD, Autade SE, Pardeshi SS (2013) Landslide hazard assessment: recent trends and techniques. Springer Plus 2:1-12

Prabu S, Ramakrishnan SS (2012) Combined use of socio economic analysis, remote sensing and GIS data for landslide hazard mapping using ANN. J Indian Soc Res 37:409-421

Pradeep Kishore V, Lakshumanan C, Viveganandan S (2012) Evaluation of limit equilibrium method for landslide susceptibility analysis (LSA) - a case study on Nilgiris district. Int J Adv Remote Sensing GIS 1:234-243

Rajarathnam S, Ganapathy GP (2006) Landslide hazard zonation of India, a GIS approach, Proceedings of the first India Disaster Management Congress, New Delhi, National Institute of Disaster Management, Government of India, pp 29-30

Rajkumar P, Sanjeevi S, Jayaseelan S, Isakkipandian G, Edwin M, Balaji P, Ehanthalingam G (2007) Landslide susceptibility mapping in a hilly terrain using remote sensing and GIS. J Indian Soc Remote Sensing 35:31-42

Ramakrishnan, S.S., Sanjeevi Kumar V., Zaffar Sadiq, M.G.S.M., Arulraj, M., and Venugopal, K., 2002, Landslide disaster management and planning - a GIS based approach. Indian Cartographer, MFDM-05, p. 192-195

Reid LM, Page MJ (2003) Magnitude and frequency of landsliding in a large New Zealand catchment. J Geomorphol 49:71-88

Seshagiri DN, Badrinarayanan S, Upendran R, Lakshmikantham CB, Srinivasan V (1982) The Nilgiris landslide - miscellaneous publication no. 57. Geol Surv India, p. 82

Squarzoni C, Delacourt C, Allemand P (2003) Nine years of spatial and temporal evolution of the La Vallette landslide observed by SAR interferometry. J Eng Geol 68:53-66

Sunandana RM, Lakshmikanta RK (2013) Image processing and dem of spatial information technology in landslide vulnerable mapping. Int J Electron Commun Comput Eng 4:129-132

Suzen ML, Doyuran V (2004) Data driven bivariate landslide susceptibility assessment using geographical information systems: a method and application to Asarsuyu catchment, Turkey. J Eng Geol 71:303-321

Thanavelu C, Chandrasekaran (2008) Geotechnical assessment of November 2006 landslides in the Nilgiris Tamil Nadu. Proceedings of the National Seminar on challenges in engineering geology (abstract), Published by Society of Engineering Geology, Hyderabad, pp 60-68

The Hindu (2009) Scale of damage in Nilgiris huge, relief work space, http:// www.thehindu.com/2009/11/12/stories/2009111258110100.htm. Accessed 12 Jan 2019.

Vaani N, Sekar SK (2012) Regional landslide hazard zonation and vulnerability analysis using AHP and GIS - a case study of Nilgiris district, Tamil Nadu, India. J Disaster Adv 5:171-176

Valadao P, Gaspar JL, Queiroz G, Ferreira T (2002) Landslides density map of S. Miguel Island, Azores archipelago. J Nat Hazards Earth Syst Sci 2:51-56
Van Westen CJ (1993) Application of geographic information systems to landslide hazard zonation. Ph-D dissertation Technical University Delft. ITC-publication number 15. ITC, Enschede, p 245

Vasantha Kumar S, Bhagavanulu DVS (2007) Effect of deforestation on landslides in Nilgiris district - a case study. J Indian Soc of Remote Sens, pp. 105-108

Varnes DJ (1984) Slope movement types and processes. In: Schuster RL, Krizek RJ (eds)Landslides, analysis and control, special report 176: Transportation research board,National Academy of Sciences, Washington, DC.,pp 11-33

Wieczorek GF (1984) Preparing a detailed landslide-inventory map for hazard evaluation and reduction: association of engineering geologists. Bulletin 21: 337-342

Yin KJ, Yan TZ (1988) Statistical prediction model for slope instability of metamorphosed rocks, proceedings of the $5^{\text {th }}$ international symposium on landslides, Science and Education Publishing, Vol 2, Lausanne, pp. 1269-1272

\section{Publisher's Note}

Springer Nature remains neutral with regard to jurisdictional claims in published maps and institutional affiliations.

\section{Submit your manuscript to a SpringerOpen ${ }^{\circ}$ journal and benefit from:}

- Convenient online submission

- Rigorous peer review

- Open access: articles freely available online

High visibility within the field

- Retaining the copyright to your article

Submit your next manuscript at $\boldsymbol{\nabla}$ springeropen.com 